\title{
Cupules and the creation of the Tewa Pueblo world
}

\author{
Samuel Duwe \\ Department of Anthropology, The University of Oklahoma, 455 W Lindsey St., Norman, U.S.A. \\ Email: duwe@ou.edu
}

\begin{abstract}
:
Stone cupules remain an enigma to archaeologists due to both their ubiquity in the archaeological record and apparent 'non-utilitarian' function. While researchers have primarily focused on the functional aspects of cupules, including their symbolic meaning, the global ethnographic record suggests that the act of creating a cupule can be as important as the resulting cupule itself. Cupules are artefacts of practice and reflect the actions, representation, and negotiations of people who were pounding on boulders and bedrock. I argue that cupule studies should move beyond ahistorical interpretation and acknowledge that the action and intentionality of creating cupules - and the resulting material remains of these practices - are subject to historical change. To illustrate this change I examine the history of the Tewa Pueblos of northern New Mexico who historically pounded cupules on landscape features to communicate with the spiritual world through prayers and offerings. I document both the morphology and landscape context of cupules associated with ancestral Tewa sites to demonstrate that while elements of cupule morphology remain constant, the context (and possibly the meaning) of cupule practice changes through time. This suggests that long-lived practices of prayer (creating cupules) were reinterpreted in the crucible of dramatic social and residential transformation.
\end{abstract}

Keywords: cupules; landscape; American southwest; Tewa Pueblos; ground stone tools

\section{Introduction}

Cupules, defined as small, often clustered, roughly hemispherical features pounded into horizontal, inclined, and vertical rock surfaces (Bednarik 2008: 62), remain an enigma in both ground stone tools research and rock art studies. This is due to both their ubiquity in the archaeological record (observed on six continents at sites dating from the Lower Palaeolithic to the twentieth century) and apparent 'non-utilitarian' function (their small size and placement on inclined and vertical surfaces make food and pigment preparation unlikely, or at least not of primary importance). The latter has led archaeologists to interpret cupules as an early and most prevalent form of rock art with symbolic or ritualistic function. The former suggests that this symbolism may have cross-cultural connotations, or at least represent similar types of human practice in landscape modification over time and space.

Although there is a growing body of research addressing the identification (Cairns \& Branagan 1992; Bednarik 1994; Clegg 2007), formation (Nelh 1986; Bednarik et al. 2005;

Published by the School of History, Classics and Archaeology, University of Edinburgh ISSN: 2055-0472. URL: http://journals.ed.ac.uk/lithicstudies/

This work is licensed under a Creative Commons Attribution 2.5 UK: Scotland License. 
Kumar \& Ram 2014; Bednarik 2008), and morphology (Gilbert 2000) of cupule features, the majority of archaeological research has focused on identifying cupule function. Some of this has been speculative, leading to claims that cupules represent star charts (Cairns \& Branagan 1992) or gaming boards (Odak 1992). Most interpretations, however, are based on ethnographic analogy. While not an exhaustive list, the ethnographic literature describes cupules as places to extract medicine (Callahan 2004), a form of weather control (Spier 1930: 21; Heizer 1953), as lithophones (Bednarik et al. 2005), use in fertility ceremonies (Stevenson 1887: 540; Fewkes 1891: 9-10; Heizer 1953; Hedges 1983a; 1983b), and as portals and places to communicate with the spiritual world (Jeançon 1911: 96, 1923: 70; Parsons 1929: 238-252; Ortiz 1969: 18-21). While the meaning and function of cupules are probably as diverse and nuanced as the myriad cultures in which they are found, the ethnographic examples do point towards an interesting point of departure: that cupules are not just features to be used, but also artefacts of practice. In short, the act of creating a cupule can be as important as the resulting cupule itself (Bednarik 2008).

If we allow that human practice is inherently dynamic, and that systems of symbols, signs, and ritual change through time (Pauketat 2001), we should anticipate that the practice and purpose of creating cupules - and the resulting material remains of these practices - are also subject to historical change. While this assertion poses challenges for archaeologists, particularly when dealing with poor temporal control inherent in the study of rock art and stone features, it also provides opportunities to begin to ask nuanced questions that both expand on these studies and address larger historical issues. These include: how did these practices evolve and change in the context of history? And what can this history of practice tell us about the actions and representations of the people who were pounding cupules into bedrock and boulders?

In this paper I address these questions through examining the history of the Tewa Pueblos of northern New Mexico who historically (Jeançon 1923: 70) pounded cupules on boulders, cobbles, and bedrock to communicate with the spiritual world through prayers and offerings (Figure 1). These features, called kayé by the Tewa (Parsons 1929: 238), in turn act as nodes in an expansive and connected sacred geography (Ortiz 1969: 18-21). Kayé help to define the shape and structure of the world and based on their placement on the landscape are identified as being used by specific people with specific purposes in Tewa social and ceremonial organization (Ortiz 1969). Although ancient, Tewa cosmography is far from static, evolving over the past eight centuries as a way to define an emerging Tewa cosmos and a transforming social and ceremonial organization (Anschuetz 1998: 437-484; Duwe 2011; Duwe \& Anschuetz 2013). Through the study of cupule morphology and the context of kayé I examine how practices relating to cupule formation and use changed and were reinterpreted in the context of dramatic social and residential upheaval.

\section{The Tewa world}

The Tewa Pueblos, who today live in six communities along a $30 \mathrm{~km}$ stretch of the northern Rio Grande and its tributaries between the cities of Santa Fe and Taos, are traditionally village dwelling maize agriculturalists who have made a living in an unforgiving, and ever changing, high desert environment for millennia. Bringing moisture and fertility to the people is of primary concern to Tewa cosmology and ceremonialism, and the Tewa's landscapes are dotted with sacred places for both priests and laypeople alike to channel these blessings to the village (Ortiz 1969: 18-21).

While the Tewa are certainly not unique in constructing cosmographies, the study of Tewa ethnography and history offers archaeologists an ideal case study to understand how people both build and interact with their landscapes. This case study serves as a valuable 
model thanks to twentieth-century ethnographers who recorded the specific ways that individuals and ceremonial societies not only conceptualized, but used, their sacred geography. The Tewa landscape is vast and nuanced, and is conceptualized as a complex network of people, nature, and the spiritual world. Within these networks are spiritual nodes, or places of particularly sacred importance, by which people can communicate with the larger cosmos. These include topographic features (mountains, springs, caves, and hills) but also smaller and sometimes less obvious places called shrines by anthropologists. Some of these blessing places consist of an eagle feather in a juniper tree (Parsons 1929: 242), or a small granite cobble indistinguishable from the thousands of its neighbours (Ortiz 1969: 21). But others, such as cupules on large boulders, are identifiable and can withstand the passage of time, whether a season or a millennium.

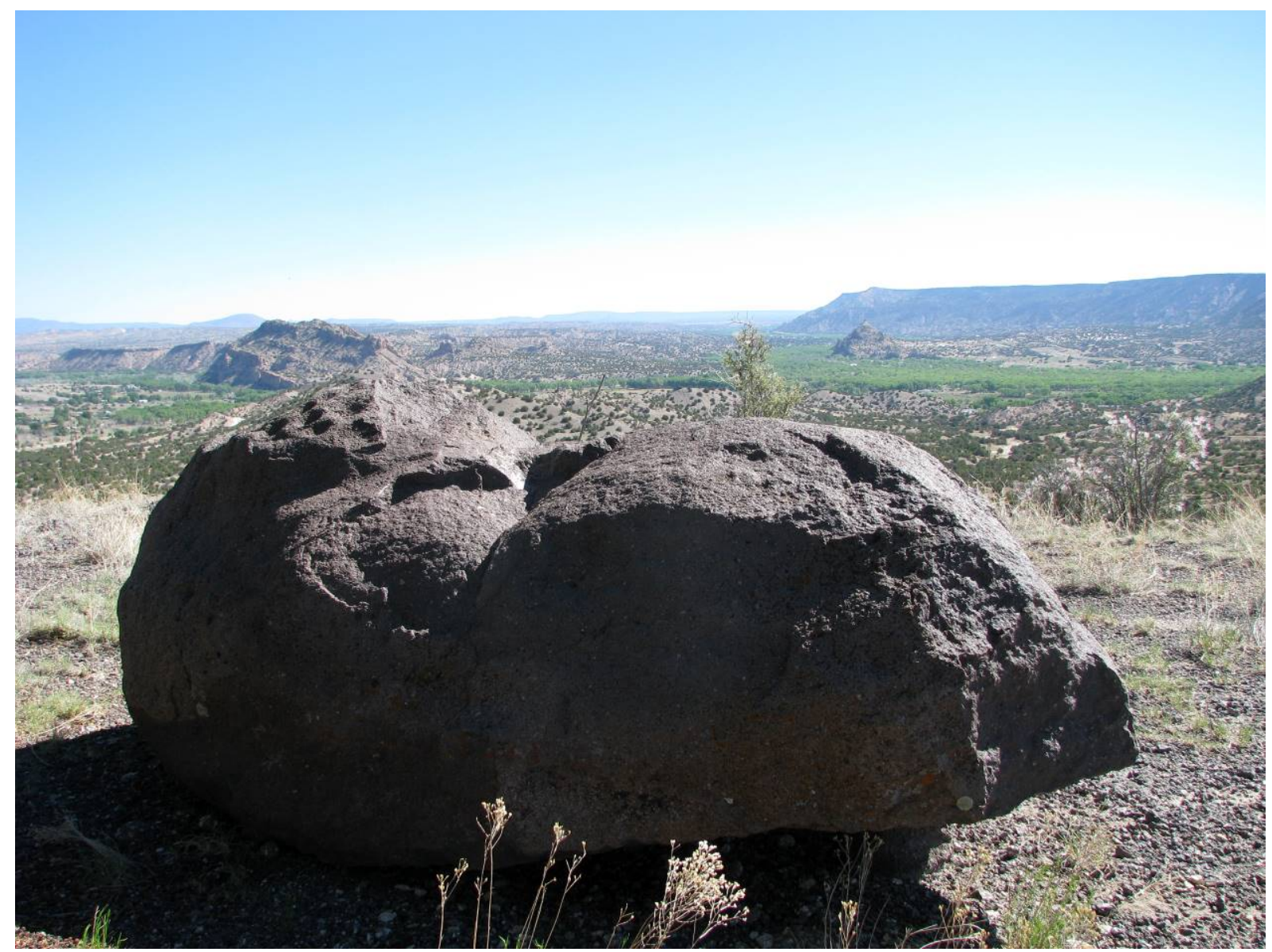

Figure 1. A kayé at the ancestral Tewa site of Ku’owingeh.

The Tewa conceptualize their world as spherical, with the earth a pottery bowl and the sky an inverted basket (Swentzell 1990). Vertical space is bounded by three levels (the current world and an upper and lower world), and horizontal space by the four cardinal directions. Horizontal space is also defined by a series of nested tiers, bounded by sacred mountain peaks and centred on the village (Ortiz 1969: 18-22). Each tier is intertwined with elements of social and ceremonial organization and hierarchy, including the homes of deities and culture heroes. The first, or outermost, tier are powerful shrines where male ceremonial leaders pilgrimage to commune with ancestral rain spirits and to pray for rain and blessings to flow to the village. The second tier, the hills and agricultural fields that surround each village, are the domain of both men and women, and upon the hills and amongst the fields are shrines devoted to hunting and growing maize. The third tier, or the space immediately adjacent to 
the village, is a place of household shrines that are kept and used by the women leaders in each home. At these shrines, households can offer prayers and communicate with the larger metaphysical world. The last tier is the village itself, the middle of middles, and represents the symbolic centre of the cosmos.

In this paper I focus on the third tier where shrines are located immediately adjacent to the village. Not only are these shrines documented in Tewa ethnography, but also are in an area most accessible to archaeologists due to its close proximity with village architecture. This allows for both the likelihood of observation and identification, and also a way to tentatively date these features by association to the village. Whereas the shrines of the sacred peaks and hills are primarily domain of the ceremonial leaders, these shrines, known as kayé (Parsons 1929), belong to the maatui'in, or household groups (Ford 2009). It is at these shrines that members of the household conduct special prayers for crop production, hunting, and the well-being of the village (Parsons 1929: 134). These kayé also act as a symbolic representation of the four-directional cosmology, with major village shrines located on the cardinal directions. Ortiz (1969: 20) describes these shrines at Ohkay Owingeh (formerly known as San Juan Pueblo) as follows:

"First in the directional circuit is Than Powa, "Sun-water-wind," represented by a pile of large stones at the northern edge of the village. At the western edge of the village in Awe Kwiyok or Spider Woman, represented by a single stone; to the south is $\mathrm{Nu} E n u$ or Ash Youth, also represented by a single stone. Approximately one mile east of the village is a low hill with a pile of stones on top; this is Ti Tan He I, or "Large Marked Shield," the shrine of the east. There are numerous other shrines dotting the landscape around each Tewa village, as is abundantly clear from Harrington's (1916) account. But these four are the principal ones of the directions, in the sense that regular, patterned usages and meaning attach to these, and not to the others. Collectively these shrines are known as Xayeh T'a Pingeh, 'Soul-dwelling Middle-places'."

It is at these Xayeh T'a Pingeh, or soul-dwelling middle-places, that the kayé take on additional meaning: as places where the souls of the deceased travel after death. Once it arrives at a kayé, the spirit is met by ancestral souls. Together they travel to all points in the Tewa world, including the mountains, hills, and other shrines on their journey back to "the lake” or place of emergence (Ortiz 1969: 52). This gives additional meaning to the placement of many of these kayé on the ash piles, or middens, where the deceased are buried (Ortiz 1969: 20).

Kayé are places that are regularly visited and cared for. Parsons (1929: 239) described one way that kayé are tended is through depositing offerings of corn meal and prayer feathers from an eagle or turkey. A Tewa consultant explained to her that the prayer feathers are "like telephones" in that they carry a message to a distance, in this case a prayer for blessings. Offerings can be more specific as well; in the case of luck with hunting the Tewa would lay bones of deer and rabbits at a shrine (Parsons 1929: 134). Ortiz (1969: 54) explained how kayé featured prominently in Tewa death rights as on the fourth day of mourning the deceased's family would hold a symbolic feast, travel to the nearest Xayeh T'a Pingeh, and drop the pot and scatter the food. A ritual would then be conducted to release the soul from the shrine and return to the afterlife.

While kayé feature prominently in the Tewa ethnography, descriptions of the creation and use of these places, particularly the practices related to cupule formation, are sparse. Valuable exceptions are buried in the archaeological reports of J.A. Jeançon $(1911 ; 1923)$ who surveyed the region and excavated ancestral Tewa sites in the early twentieth century. When questioning his consultant from Santa Clara Pueblo about a large boulder with numerous cupules at the site of Ku'owingeh (Figure 1), Jeançon (1911: 96) learned that this 
was a place where the Tewa "went every morning to pray for strength, the cups being made by the worshippers pounding on the rock to attract attention of the gods."

This same consultant was queried about nine cupules that covered a different large boulder on the south edge of the Poshu'owingeh, a rock that also had rock art and additional ground features (Figure 2). He learned that "at certain times of the year, and during certain ceremonies, it was and still is the custom for women to go at daybreak and pound on the rocks to attract the attention of the 'Sun god.' The same rocks were always used, and that accounted for the holes.” Both boulders were defined as an important places by Jeançon's consultant and based on their size, location, and prominence at the sites were likely a Xayeh T'a Pingeh. The cupules that Jeançon observed at these sites, and across the northern Rio Grande region, are therefore the echoes of past prayers and permanent reminders of how the ancestral Tewa communicated with their larger world.

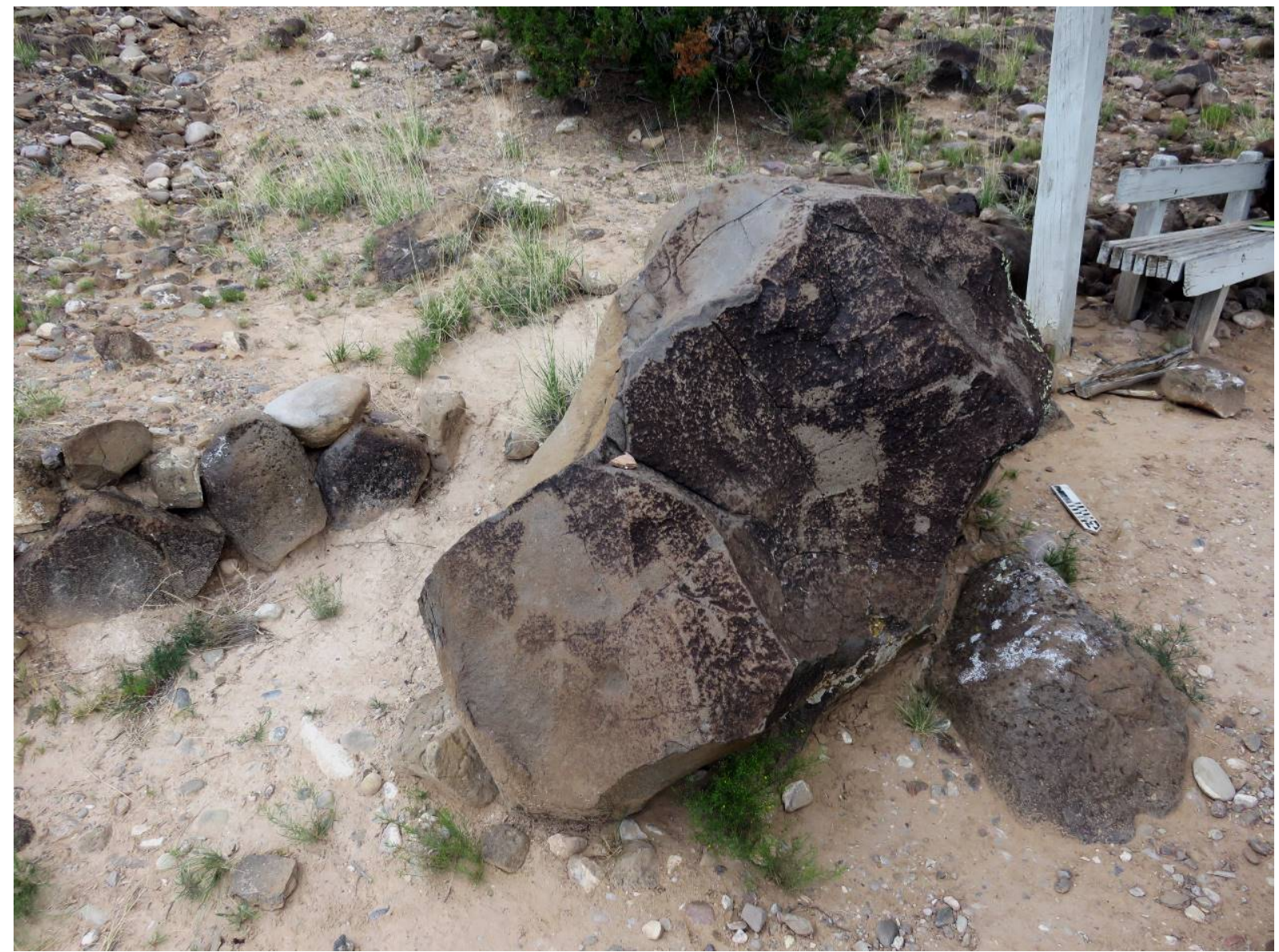

Figure 2. The Xayeh T’a Pingeh kayé described and interpreted at Poshu'owingeh by Jeançon (1923). Note the cupules below the bird petroglyph in the foreground.

\section{Tewa history and the Rio Chama watershed}

Jeançon's information stemmed from a Tewa interpretation of a kayé dating to the fifteenth century. In subsequent decades archaeologists working in the northern Rio Grande region have observed these 'cupule shrines' in archaeological contexts dating from the thirteenth to the seventeenth century (Anschuetz 1998: 449-480; Snead 2008: 81-112; Fowles 2009). Using ethnographic analogy and the direct historical approach, archaeologists have assumed that these shrines have a similar purpose to those of the historic and modern era: a way to encourage and channel blessings between the people and their world. However, recent research has found that Tewa landscapes are not static but have evolved and changed 
significantly throughout history. The Tewa world is not a monolithic whole, but rather the result of a complex history of migration (Ford et al. 1972; Ortman 2012), population coalescence (Duwe 2011: 275-311; Duwe \& Anschuetz 2013), and foreign domination (Barrett 2002).

Archaeological data (Duwe 2011: 252-260; Ortman 2012; Duwe \& Anschuetz 2013) and Tewa oral tradition (Ortiz 1969: 13-16; Parsons 1994: 9-15) suggest that at least two generalized populations converged in the late thirteenth and early fourteenth centuries in the Tewa Basin, the aboriginal homeland of the Tewa Pueblos located between the modern cities of Santa Fe and Taos. These include autochthonous villagers who had lived in the region for millennia and migrant communities from the northern Southwest who were displaced by drought. These disparate peoples began to settle in the Rio Chama watershed, a previously unoccupied corner of the Tewa Basin, by the mid-thirteenth century. The Rio Chama watershed offers archaeologists an excellent case study to understand the development of Tewa cosmography in the context of historical negotiation between diverse populations. In this brief discussion of Tewa history I focus on the archaeology of the Chama, and particularly on the kayé surrounding ancestral villages.

The newly arrived settlers in the Chama built small villages and hamlets along both the river courses and highland areas beginning in the mid-thirteenth century (Duwe 2011: 252260), the beginning of the Late Coalition period (A.D. 1250-1350). Some of these villages contained upwards of 500 rooms (Trott \& Taylor 1994) but most were small (30-100 rooms) and likely housed multiple families (Duwe 2011: 259). Surrounding these sites are boulders and cobbles with cupules (and also grinding slicks) that are akin to those described in Tewa ethnography (Jeançon 1911: 96; 1923: 70). While these kayé are similar to those associated with later occupations, their limited numbers, diversity in landscape patterning between contemporary sites, and lack of directional Xayeh T'a Pingeh suggest that these settlers did not conceptualize the space surrounding their villages in the same way as their descendants (Duwe 2011: 349-370). In fact, due to the heterogeneity of landscape practices between nearby villages (see Section 5.4) it is possible that these people did not conceptualize their worlds in the same ways as their neighbours. However, it is difficult to discreetly date these kayé (and their cupules) to the Late Coalition period. In Tewa cosmography ancient sites are enshrined on the landscape (Harrington 1916) and are regularly visited on pilgrimage (Anschuetz 1998: 467). Hence some of the kayé associated with Late Coalition sites may have been constructed, and used, by later people. However, it is probable that many of these kayé were established in the thirteenth century based on contemporary landscape practices across the northern Rio Grande region (Snead 2008: 81-112; Fowles 2009).

This pattern changed dramatically at the beginning of the Classic period (A.D. 13501598) with a major transformation in the size, density, and organization of residential settlements. Small villages and hamlets were depopulated as people resettled in fewer, but much larger (many over 1,000 rooms) villages along and near well-watered valley bottoms. Architectural, ceramic, and settlement data suggest that these diverse coalescing peoples came together at sites of unprecedented size and created a social and ceremonial organization pattern similar to that described in Tewa ethnography (Duwe 2011: 370-394). In the process of becoming Tewa, the residents of the Chama also appear to have transformed their cosmography. Classic period villages are associated with landscapes that are similar to those discussed by Parsons (1929: 238-254) and Ortiz (1969: 18-21) and include many kayé, some which are placed at cardinal directions (Anschuetz 1998: 449-480). In addition, ancestral Tewa sites in the watershed express a similar spatial 'logic' and this homogeneity belies a shared identity and cosmology across the region (Duwe 2011: 370-394; Duwe \& Anschuetz 2013). 
Spanish colonization of New Mexico began in 1598 and permanent Tewa residence of the Rio Chama watershed appears to have ceased by the early-seventeenth century. The presence of Spanish missionaries and government officials severely restricted movement beyond their Historic period (A.D. 1598 -) villages, but the Tewa did not abandon their ancestral homeland and continued to travel through the region for short term (likely seasonal) residence and resource procurement (Barrett 2002). Because ancestral sites are viewed as sacred, the Tewa continued to visit these places constructing and utilizing kayé, in some cases on the ruins themselves (particularly at the site of Ku'owingeh discussed below).

This recent research demonstrates that there are changes in how the Tewa constructed the structure of their cosmographies through time, particularly through the coalescence of diverse people into large villages in the fourteenth century. One aspect that is missing, however, is how people themselves were interacting with and using these landscapes. In short, how can we be sure that a kayé had the same use between the Late Coalition and Historic periods? If this use changed (or remained the same) what does that tell us about the meaning of kayé and the development of the social and ceremonial groups that used them? Fortunately, many kayé do have evidence of this use in the form of cupules pounded on their surface. The study of cupule morphology in the context of space and Tewa history is a place to start addressing these questions.

\section{Materials and methods: surveying for kayé}

The present study is part of a larger project that documents the sacred geography surrounding ancestral Tewa sites in the Rio Chama watershed dating to the Late Coalition, Classic, and Historic periods (Duwe 2011: 318-397). My focus here is on 12 sites with an accompanying 70 kayé and an associated 675 cupules (Figure 3, Table 1). These sites were selected because they span the length of Tewa history from the thirteenth to seventeenth centuries and were accessible for landscape survey.

Understanding that the Tewa created meaningful cosmographies is one thing, but identifying, interpreting, and dating these places over 700 years later is quite another. Only a portion of Tewa sacred geography is available to study. This stems partly from differential preservation as many kayé described in Tewa ethnography were made of living or perishable material that do not withstand time or the elements (Parsons 1929: 238-249). Human impacts can influence these landscapes as well. For example, the seventeenth-century Hispanic residents of the Chama watershed scavenged the large kayé boulders at the Classic period site of Pesede'owingeh to build house foundations and walls in their agricultural fields (Duwe 2011: 320). And the site of Ponshipa'akeri'owingeh, one of the longest-occupied sites in the Rio Chama watershed, has very few visible shrines that can be distinguished due to extensive blading of the site for ranching activities in the historic and modern era (Bugé 1978).

Identifying kayé offers additional challenges. Tewa ethnography demonstrates that while kayé can have crucial importance they are often comprised of unremarkable stones with no human modification (Parsons 1929: 238). Many are simply a single boulder or a collection of upright stones and are invisible to archaeologists even with the aid of ethnographic analogy. Therefore only the largest and most prominent, but not necessarily the most important, can be reasonably identified and analysed. Fortunately, this project focuses specifically on kayé with associated cupules that were the consequence of intentional modification of natural rock face. While these shrines do not represent the entire sacred geography surrounding an ancestral Tewa site they do allow archaeologists to begin to understand how landscapes change through time. To identify these kayé I relied on multiple resources including ethnographic descriptions (Jeançon 1911, 1923: 70-73), previous archaeological research in northern New Mexico 
(Anschuetz 1998: 449-480; Fowles 2004: 497-550; Snead 2008: 81-112; Fowles 2009), and consultation with Tewa communities.

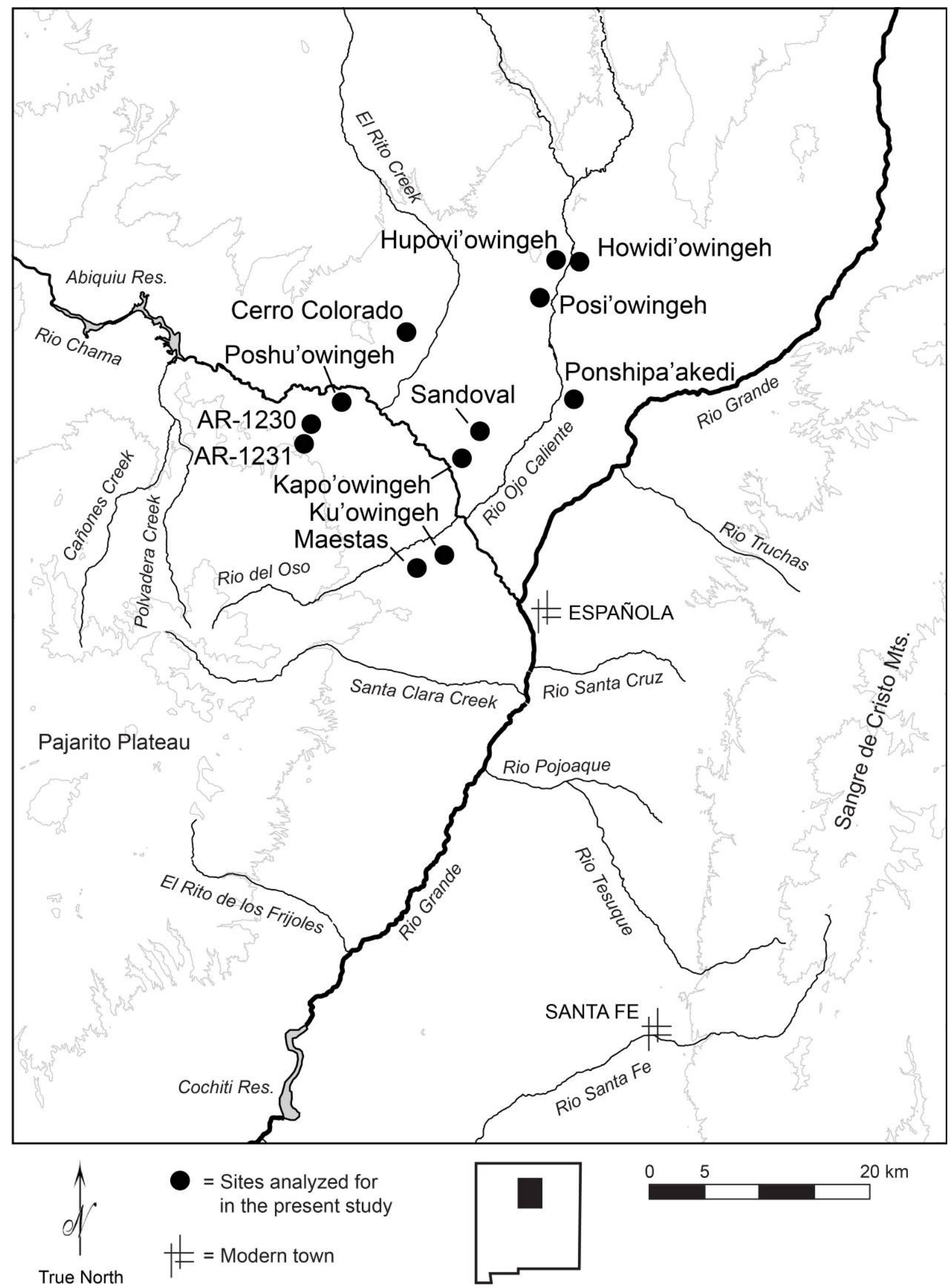

Figure 3. Map of Late Coalition and Classic period sites in the Rio Chama watershed analysed for this project. 
Table 1. Sites from the Rio Chama watershed analyzed for this project.

\begin{tabular}{lcccc}
\hline Period and Site & Site No. & \multicolumn{1}{c}{ Dates } & Rooms & Kayé (cupules) \\
\hline Late Coalition & & & & $11(86)$ \\
Kapo'owingeh & 300 & A.D. 1300-1350 & 145 & $5(39)$ \\
Maestas Pueblo & 90844 & A.D. 1275-1350 & 39 & $2(40)$ \\
AR-03-10-06-1230 & 147926 & A.D. 1275-1350 & 100 & $3(6)$ \\
AR-03-10-06-1231 & 147927 & A.D. 1300-1350 & 40 & $1(1)$ \\
\hline Late Coalition and Classic & & & & $10(162)$ \\
Ponshipa'akedi'owingeh & 297 & A.D. 1312-1550 & 1,535 & $1(1)$ \\
Tsama'owingeh & $908-909$ & A.D. 1251-1550 & 1,518 & $4(17)$ \\
Sandoval Pueblo & 98319 & A.D. 1322-1394 & 136 & $6(144)$ \\
\hline Classic & & & & $43(402)$ \\
Howidi'owingeh & 71 & A.D. 1377-1537 & 1,428 & $3(18)$ \\
Ku'owingeh & 253 & A.D. 1366-1500 & 521 & $16(253)$ \\
Poshu'owingeh & 274 & A.D. 1375-1500 & 1,114 & $10(37)$ \\
Cerro Colorado & 370 & A.D. 1350-1425 & 550 & $1(1)$ \\
Hupovi'owingeh & 380 & A.D. 1363-1550 & 948 & $6(27)$ \\
Posi'owingeh & 608 & A.D. 1344-1500 & 2,204 & $7(66)$ \\
\hline Historic & & & $5(25)$ \\
Ku'owingeh & 253 & post A.D. 1600 & & $5(25)$ \\
\hline Total & & & & $70(675)$ \\
\hline
\end{tabular}

Lastly, kayé, like all rock art and stone features, are notoriously difficult to date. I indirectly dated these features based on their proximity to scatters of diagnostic pottery and dated occupations. Sites that span multiple time periods (Ponshipa'akedi'owingeh, Tsama'owingeh and Sandoval Pueblo) were excluded from temporal comparison. This type of dating is challenging, however, because the Rio Chama watershed represents an accretional landscape where both ancient sites and kayé continue to retain their importance in Tewa cosmography. Later people can alter earlier landscapes. For example, kayé associated with Late Coalition period sites may have been both built and used by Tewa from the Classic and Historic periods, and Classic period landscapes may have been added to and changed by Historic period people. In some cases the context of the kayé can clarify its temporal association. At the Classic period site of Ku'owingeh five kayé were identified on the top of the collapsed architecture. Because adobe architecture falls to ruin without constant maintenance (Cameron 1999; Duwe et al. 2015) these shrines were therefore established after the village had been depopulated in the mid-sixteenth century, and most likely date into the Historic period (Anschuetz 1998: 467; Duwe 2011: 395). Regardless of the problematic nature of dating kayé (which I note through the following discussion) chronological comparison is useful in that it is possible to observe dramatic transitions in landscape from early to later periods, and also establishes trends to build multiple hypotheses of ancestral Tewa landscape use.

To locate and identify kayé I directed crews ranging from one to four people to systematically survey the landscape immediately adjacent to a site's architecture (within 0.5 $\mathrm{km})$. For the sake of efficiency I conducted unsystematic survey beyond this distance up to 2 $\mathrm{km}$ from the villages to include hilltops, ridges, and other prominent features where the ancestral Tewa were likely to build kayé. All potential shrines were recorded, photographed, and spatially located using a Trimble GPS unit and the resulting data was incorporated into a GIS database. A number of attributes were recorded for each kayé including size of rock 
(length, width, height), rock type (basalt, granite, sandstone, or conglomerate), the number of cupules, compass directionality of cupules on rock face, and angle of rock face where cupules were present. Preliminary morphological data was also collected including measuring the width and depth of the smallest and largest cupule on each kayé which were then averaged.

\section{Results}

A total of 675 cupules were observed on 70 kayé from 12 sites in the Rio Chama watershed. These kayé are primarily located on the edges of site architecture and often built on the tops of midden deposits, the traditional places of burial in Pueblo culture. These shrines (identified using the criteria in Section 5.1) encompass a great degree of morphological variability, but are often comprised of a small to medium-sized boulder with anywhere from one to one hundred cupules on the visible rock face. In general, cupules range from 1-6 cm wide and 0.5-2 cm deep. In this section I present the results of this analysis and focus on both cupule morphology and context to understand changes in Tewa landscape practice. Before I begin, however, it is necessary to explain how I identified cupules and how the petrology of kayé affects morphological analysis.

\subsection{Identification}

Jeançon (1923: 70) describes Tewa cupules as the consequence of repeated pounding by women on large boulders surrounding the village in the act of prayer. This, in general, fits the global definition of cupules provided by Bednarik (2008: 70) that includes three primary characteristics: 1) A cupule must be human-made bedrock feature and not naturally occurring, 2) It must be made by numerous blows of percussion, and 3) It must possess a non-utilitarian or symbolic function.

To satisfy Bednarik's first and second characteristics I identified cupules as being human made through percussion blows. Numerous environmental processes such as differential erosion, solution via ground and rain water, and natural voids in a rock surface can lead to features that resemble cupules. To account for this possibility I identified cupules with visible scarring that appear to be the result of striking the rock surface with another stone (Figure 4). However, many cupules, particularly on basalt, did not show signs of pounding but were still identified as cupules. I feel comfortable in my identification because cupules on boulders and cobbles are relatively rare, and based on my experience conducting unsystematic survey through the Chama are located primarily adjacent to village architecture. I also erred on the side of caution and did not include cupules with questionable formation processes.

Bednarik's third characteristic - defining cupules as non-utilitarian and symbolic - is more problematic. He specifically means that cupules are not primarily used for processing material such as food or pigment, and therefore are distinguished from other stone features such as mortars. In this regard his definition applies to Tewa cupules. 57.1 percent $(n=40)$ of kayé have at least one cupule on a rock face angle of greater than 45 degrees. Preparing food or pigment on a non-horizontal surface is impractical and suggests that the majority, if not all, Tewa cupules were the result of other kinds of practice. However, applying a functional label of 'symbolic' to features that cannot be explained as having 'utility' presupposes that a postEnlightenment secular-sacred distinction can be applied onto the past (Brück 1999). Certainly the Tewa view cupules as serving a crucial role in subsistence; Tewa ethnography describes these cupules as the consequence of prayers that encourage rain and fertility for the fields to feed the people. This distinction is not just semantic and instead refocuses attention on cupules as the result of human action. 


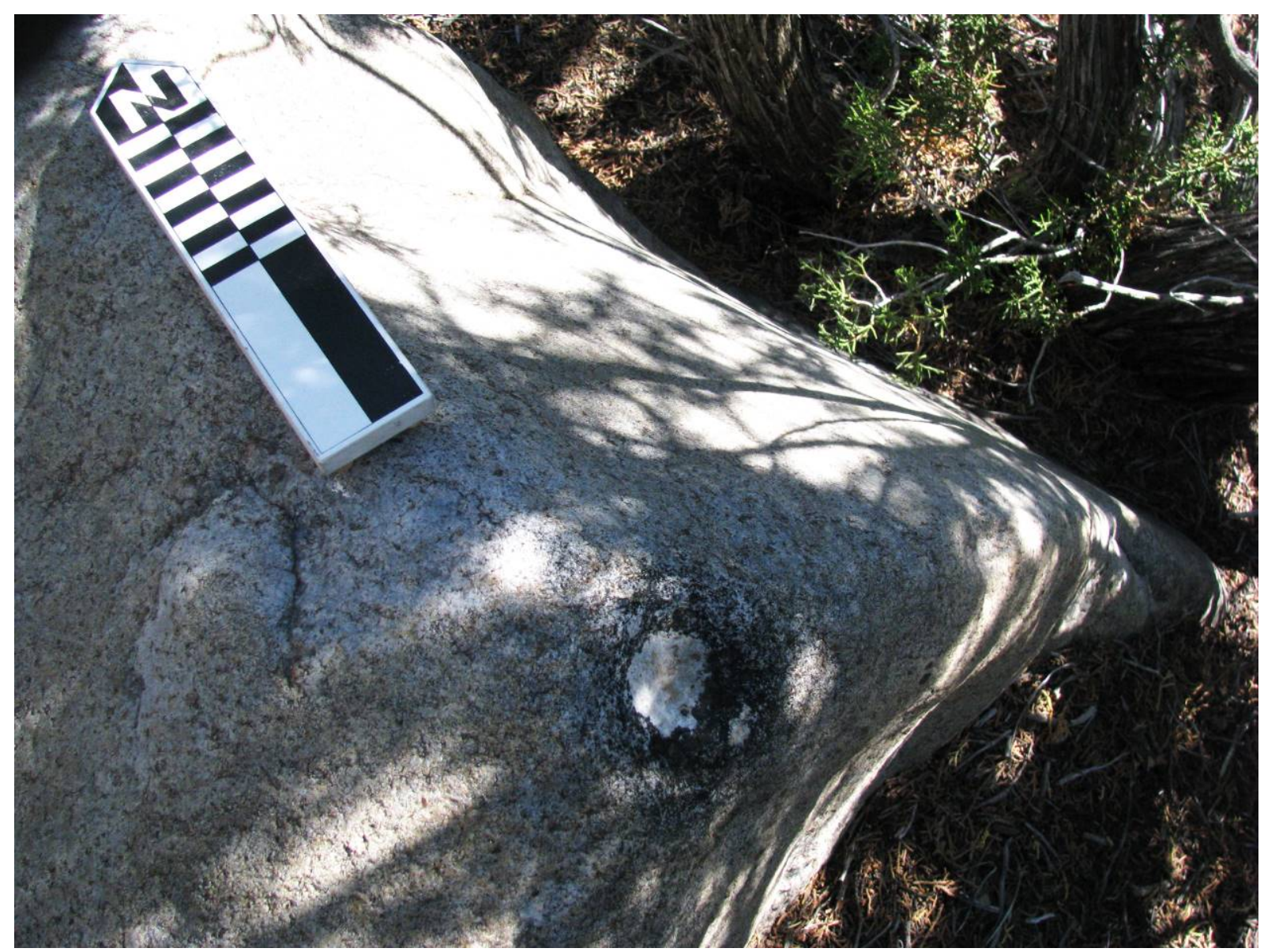

Figure 4. A cupule with pounded marks at Hupovi’owingeh.

\subsection{Petrology}

The geological history of the Rio Chama watershed is complex and defined by a variety of land-transforming processes including marine deposition, volcanism, and erosion. The resulting rock types (basalt, granite, sandstone, and conglomerate) were used by the ancestral Tewa to construct kayé, with the majority (97\%) comprised of basalt and granite (Table 2). Rock choice was likely a product of what was readily available to the ancestral Tewa. While basalt dominates the assemblage (79\%), mirroring the easy access to this rock type via the Tertiary basalt flows across the Chama (Smith 1938), kayé composed of granite are found at sites along the Rio Ojo Caliente valley (Howidi'owingeh, Hupovi'owingeh, and Posi'owingeh) near localized granitic outcrops (Muehlberger 1960). However, we cannot discount cultural reasons, for Parsons (1929: 134) states that it was colour, and not shape, that dictated rock choice for the ethnographic Tewa. The white-grey hue of granite provides a stark contrast in a landscape dominated by black basalt rock.

Regardless of the reasons for selecting different types of rock, these choices affect the resulting morphology of the cupule itself. Comparing the average width and depth of cupules on the four rock types reveals two patterns (Table 3). The first is softer rock yields larger cupules, a pattern that is supported through Bednarik's (2008: 87-88) causal relationship between cupule size and petrology. Although sample size is very small, sandstone cupules appear significantly wider and deeper, and conglomerate deeper, than cupules on basalt and granite. The second pattern is that cupules on basalt and granite (the majority of the assemblage) are similar in size. A two-tailed student's t-test for independent means demonstrates no significance difference at the .01 level in the mean values of both width $(\mathrm{t}=$ 2.74, $\mathrm{df}=32, \mathrm{p}=0.9299)$ and depth $(\mathrm{t}=2.72, \mathrm{df}=37 \mathrm{p}=0.0446)$. Whether this is a 
consequence of similar size hardness of rock types, or a conscious effort to engage in practice that results in cupules with similar morphology, is an open question. However, this similarity allows for kayé composed of basalt and granite to be grouped together for comparison of morphological variation through time.

Table 2. Counts of kayé by site, period, and rock type.

\begin{tabular}{lccccc}
\hline & \multicolumn{5}{c}{ Number of kayé (number of cupules) } \\
\cline { 2 - 6 } Period and Site & Total & Basalt & Granite & Conglomerate & Sandstone \\
\hline Late Coalition & $11(86)$ & $11(86)$ & - & - & - \\
Kapo'owingeh & $5(39)$ & $5(39)$ & - & - & - \\
Maestas Pueblo & $2(40)$ & $2(40)$ & - & - & - \\
AR-03-10-06-1230 & $3(6)$ & $3(6)$ & - & - & - \\
AR-03-10-06-1230 & $1(1)$ & $1(1)$ & - & - & - \\
\hline Late Coalition and Classic & $11(162)$ & $11(162)$ & - & - & - \\
Ponshipa'akedi'owingeh & $1(1)$ & $1(1)$ & - & - & - \\
Tsama'owingeh & $4(17)$ & $4(17)$ & - & - & - \\
Sandoval Pueblo & $6(144)$ & $6(144)$ & - & - & - \\
\hline Classic & $43(402)$ & $28(306)$ & $13(92)$ & $1(3)$ & $1(1)$ \\
Howidi'owingeh & $3(18)$ & $2(15)$ & $1(3)$ & - & - \\
Ku'owingeh & $16(253)$ & $16(253)$ & - & - & - \\
Poshu'owingeh & $10(37)$ & $9(36)$ & $1(1)$ & - & - \\
Cerro Colorado & $1(1)$ & - & - & - & $1(1)$ \\
Hupovi'owingeh & $6(27)$ & $1(2)$ & $5(25)$ & - & - \\
Posi'owingeh & $7(66)$ & - & $6(63)$ & $1(3)$ & - \\
\hline Historic & $5(25)$ & $5(25)$ & - & - & - \\
Ku'owingeh & $5(25)$ & 5 & - & - & - \\
\hline Total & $70(675)$ & $55(579)$ & $13(92)$ & $1(3)$ & $1(1)$ \\
\hline
\end{tabular}

Table 3. Measurements of width and depth between kayé rock types. Abbreviates: N/A - not applicable.

\begin{tabular}{llcccc}
\hline \multicolumn{2}{l}{ Measurement } & Basalt & Granite & Conglomerate & Sandstone \\
\hline Width (cm) & Mean & 3.9 & 4.0 & 2.8 & 4.0 \\
& Std. Dev. & 1.0 & 0.6 & N/A & N/A \\
Depth (cm) & Mean & 1.0 & 0.8 & 2.0 & 1.5 \\
& Std. Dev. & 0.6 & 0.3 & N/A & N/A \\
\hline
\end{tabular}

\subsection{Morphology}

My preliminary measurement of cupule morphology (width and depth) encompasses elements of the practice that created cupules: the size of tools used for percussion, the angle that a kayé was struck, and the duration or intensity over which this practice took place. Although my measurements are crude, I assume that similar morphology indicates similar practice, and vice versa. To compare cupule size through time, and specifically from kayé associated with Late Coalition, Classic, and Historic period sites, I included only kayé composed of basalt and granite (see discussion above). I also excluded cupules from Ponshipa'akedi'owingeh, Tsama'owingeh, and Sandoval Pueblo that cannot be reliably dated (these sites span both the Late Coalition and Classic periods) resulting in a total of 57 kayé with an associated 509 cupules. Comparing measurements of mean, standard deviation and 
the coefficient of variation between the width and depth of these cupules reveals two patterns (Table 4).

Table 4. Measurements of width and depth between kayé rock types.

\begin{tabular}{llcccc}
\hline Measurement & & Late Coalition & Classic & Historic & Total \\
\hline Width (cm) & Mean & 4.0 & 3.9 & 3.9 & 4.0 \\
& Std. Dev. & 1.3 & 0.8 & 1.6 & 1.0 \\
& CV & 32 & 21 & 41 & 25 \\
Depth (cm) & Mean & 1.4 & 0.8 & 1.3 & 1.0 \\
& Std. Dev. & 1.1 & 0.3 & 0.7 & 0.6 \\
& CV & 76 & 38 & 58 & 61 \\
\hline & & $\mathbf{1 1}$ kayé, & $\mathbf{4 1}$ kayé, & $\mathbf{5}$ kayé, & $\mathbf{5 7}$ kayé, \\
& & $\mathbf{8 6}$ cupules & 398 cupules & $\mathbf{2 5}$ cupules & $\mathbf{5 0 9}$ cupules \\
\hline
\end{tabular}

The first pattern is that there is little difference in mean width between cupules associated with sites from the three time periods. A two-tailed student's t-test for independent means demonstrates no significant statistical difference at the .01 level in the mean values of width between the Late Coalition and Classic periods $(\mathrm{t}=3.01$, $\mathrm{df}=13, \mathrm{p}=0.9518)$, and again between the Classic and Historic periods $(\mathrm{t}=4.61 \mathrm{df}=4, \mathrm{p}=0.9067)$. This suggests that the practice of creating cupules remained similar from the thirteenth to eighteenth century. Of course there is the possibility that some kayé (and their cupules) associated with earlier sites were established and used by later people. However, based on the statistically-significant uniformity of cupule width across both time and space I propose that this parity represents an ancient and deeply-rooted practice of cupule formation. If it is reasonable to extend ethnographic descriptions of how and why cupules were created into the past then the cupules represent a long history of ancestral Tewa people communicating with, and praying for, their people and world.

The second pattern is that associated with Late Coalition period sites are deeper than those of the Classic and Historic periods. Cupule depth represents either the intensity or duration of kayé use through direct percussion. Based on dates established by dendrochronological and ceramic analyses (Table 1) the average occupation of a Late Coalition period village (62.5 years) is less than half that of sites dating to the Classic period (139.5 years). The combination of a shorter span of occupation and greater cupule depth suggest an intense use of kayé. This may be the result of cosmographic practices that place more attention on fewer shrines, a pattern that was altered in the Classic period as more and different classes of kayé were available on the landscape. Alternately, the greater depth of Late Coalition period cupules may be the result of a long duration of use, namely that these sites and their kayé were revisited in the subsequent Classic and Historic periods. If this is true then this activity was not uniform across the landscape as evident by a relatively higher coefficient of variation in cupule depth at Late Coalition period sites. Two sites in particular Maestas Pueblo and AR-03-10-06-1230 - are associated with cupules of substantial depth and may have been places where some kayé were revisited and used by later people. Both of these small sites were established in the late-thirteenth century and may include some of the oldest kayé in the Rio Chama watershed. Regardless of depth, kayé across space and time have similar widths and therefore were likely part of a long history of similar practice.

\subsection{Context}

The morphological analysis demonstrated that while there is variability in cupule depth between the Late Coalition and Classic periods, cupule width essentially remains the same. I 
interpret this as indicating that the practice of creating cupules, as a form of prayer and offering, has a long and ancient history. However, the context, and content of these prayers likely changed though time in the crucible of residential and societal change. In Section 3 I briefly illustrated how recent landscape analyses (Anschuetz 1998: 449-480; Duwe 2011: 318-397) in the Rio Chama watershed have demonstrated how sacred geographies surrounding Classic period sites are dramatically different from those in the Late Coalition period. When this landscape context is combined with the morphological variability of cupules themselves we gain a better picture of how people were not only constructing, but using, their landscape.

Late Coalition period sites are generally associated with a much smaller number of kayé than later sites, probably due to a small population (40-145 rooms) with fewer households. With the possibility that some of these kayé were established or used by later groups this pattern becomes even starker. What primarily distinguishes Late Coalition period sites, however, is 1) A lack of a structured sacred geography similar to that described in Tewa ethnography, and 2) A diversity in landscapes between contemporary sites. Figure 5 demonstrates this heterogeneity between the contemporaneous sites of Maestas Pueblo and Kapo'owingeh, which may stem from a settlement history of disparate people. This pattern changes dramatically in the Classic period where kayé become more numerous, patterns of kayé are more homogenized between sites, and different classes of kayé appear on the landscape.
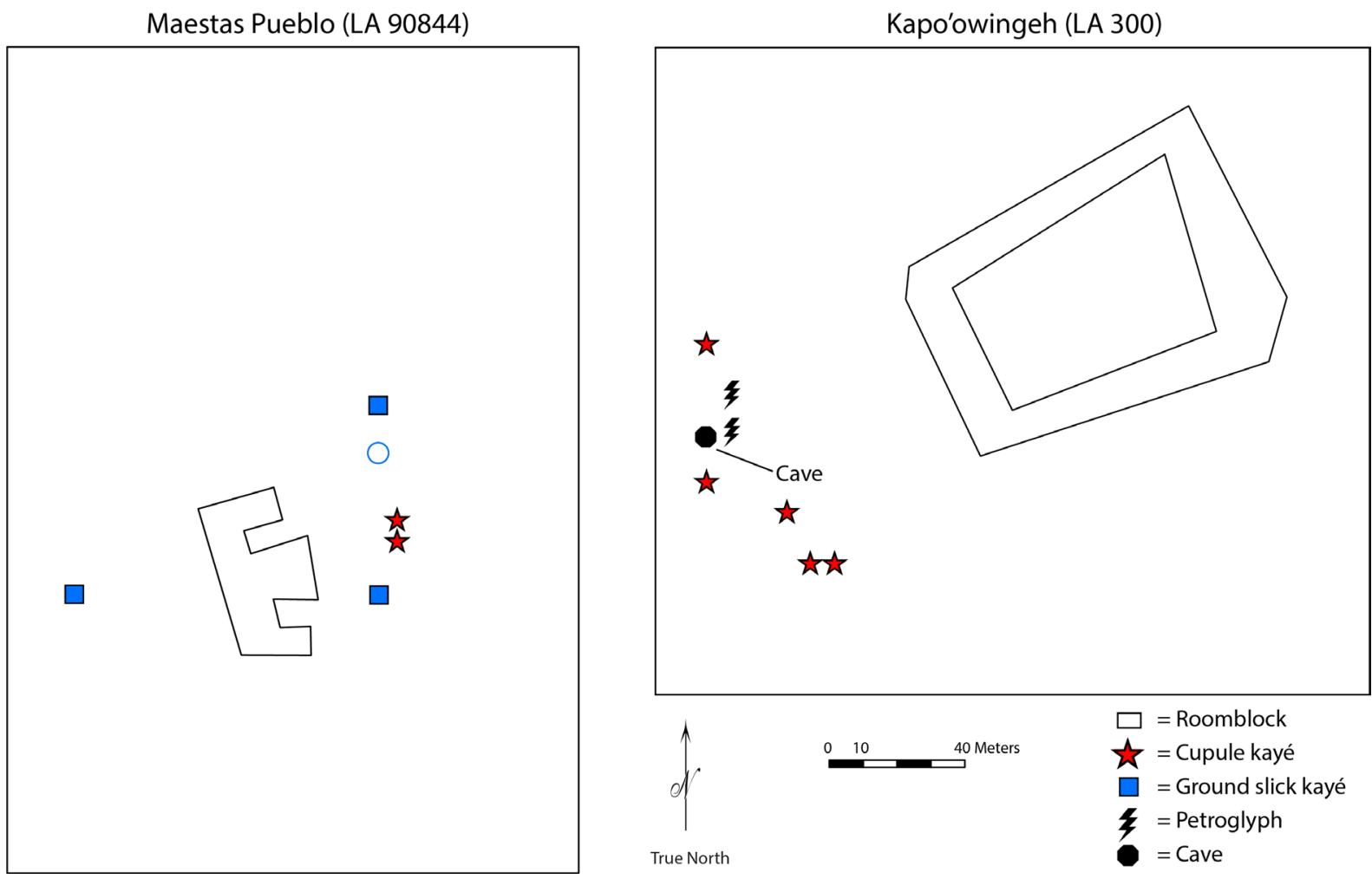

Figure 5. Kayé with cupules, and associated landscape features, at the Late Coalition period sites of Maestas Pueblo and Kapo'owingeh. [NOTE (23 JUNE 2017): This figure has been modified at the request of the author.]

An essential part of the ethnographic Tewa landscape is the presence of the primary village shrines known as Xayeh T'a Pingeh. Through the combination of both the morphological analysis and landscape context it is possible to identify these features in the Classic period. I particularly examine two of the best preserved, and most complete, Classic period landscapes at the sites of Ku'owingeh and Posi'owingeh. 
While I observed 16 kayé with an associated 253 cupules at Ku'owingeh, four kayé particularly stand out from the others: Kayé 1, 8, 10, and 16 (Figure 6). These fit the description given by Ortiz (1969) of Xayeh T'a Pingeh as being placed roughly on cardinal directions and associated with midden deposits (kayé 8, 10, and 16). These kayé were among the largest and most prominent, and also were comprised of 52 percent of the cupules at the site. Each of these kayé are also associated with a larger mortar (Figure 7). While only future use-wear analysis may explain what these mortars were used for, they were only observed at these four kayé. I compared the width and depths of these kayé with others from (Table 5). While the widths are nearly identical the cupules are slightly deeper, suggesting that these were most intensely used communally and not by one household, as is also described in Tewa ethnography.

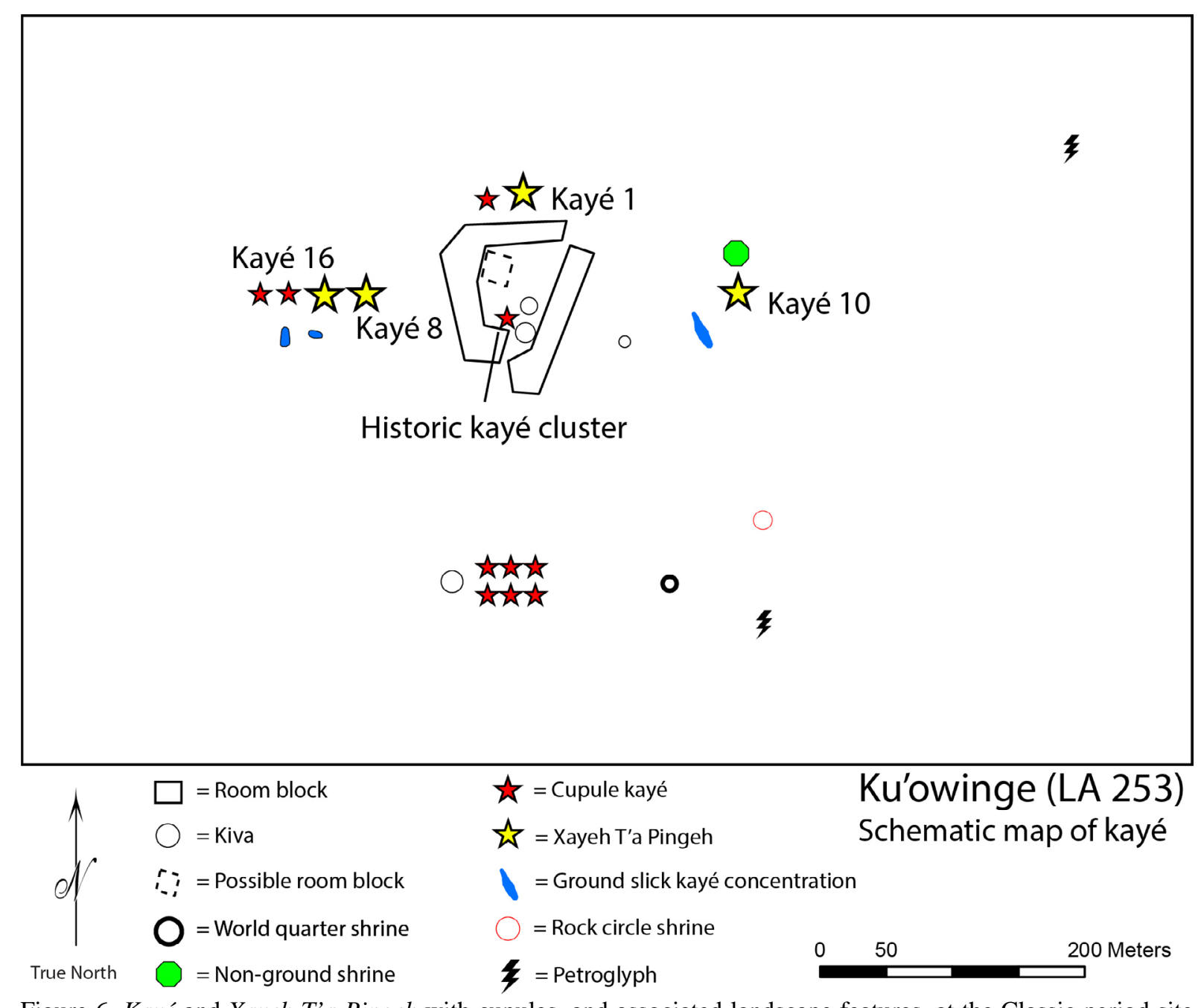

Figure 6. Kayé and Xayeh T'a Pingeh with cupules, and associated landscape features, at the Classic period site of Ku'owingeh. [NOTE (23 JUNE 2017): This figure has been modified at the request of the author.]

The possibility exists that these Xayeh T'a Pingeh were revisited and used by later groups, accounting for the deeper cupules. Ku'owingeh was certainly visited by Tewa pilgrims in the Historic period resulting in five kayé on top of the architectural rubble (Figure 6). However, if these Xayeh T'a Pingeh were revisited and worked it is unlikely that they were established by Historic period people. Ortiz (1969: 20) describes these shrines as a vital part of an active and living Tewa community and their reuse only substantiates the power of such places. 


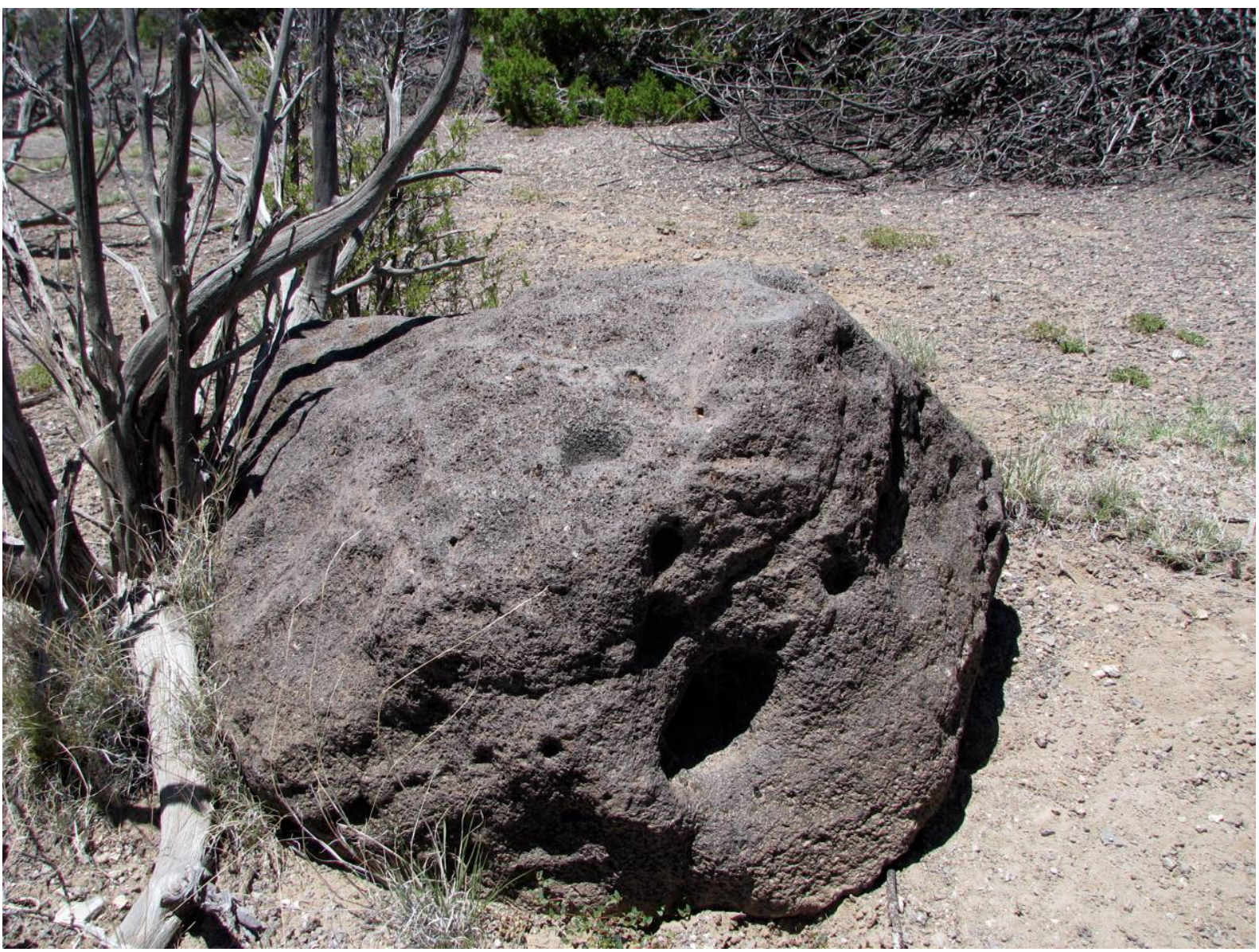

Figure 7. A Xayeh T’a Pingeh (Kayé 8) with cupules and a mortar at Ku’owingeh.

Table 5. Measurements of width and depth between Xayeh T'a Pingeh and other kayé at Ku'owingeh and Posi'owingeh.

\begin{tabular}{llccc}
\hline Site & Measurement & Xayeh T'a Pingeh & Other Kayé \\
\hline Ku'owingeh & Count & & 4 (129 cupules) & 12 (124 cupules) \\
& Width & Mean & 4.4 & 4.3 \\
& & Std. Dev. & 0.9 & 1.0 \\
& & CV & 0.2 & 0.2 \\
& Depth & Mean & 1.1 & 0.7 \\
& & Std. Dev. & 0.5 & 0.2 \\
& & CV & 0.5 & 0.3 \\
\hline Posi'owingeh & Count & & 3 (59 cupules) & 3 (4 cupules) \\
& Width & Mean & 3.6 & 3.8 \\
& & Std. Dev. & 0.6 & 0.8 \\
& & CV & 0.2 & 0.2 \\
& Depth & Mean & 1.1 & 0.7 \\
& & Std. Dev. & 0.3 & 0.3 \\
& & CV & 0.3 & 0.4 \\
\hline
\end{tabular}

This pattern of establishing Xayeh T'a Pingeh in the Classic period is also observed at Posi'owingeh. Of the seven kayé surrounding the village (Figure 8) three are exceptional (kayé 4, 6, and 9) with 89 percent of all cupules at the site were pounded on these shrines. These kayé are located on the north, west, and south sides of the village. The lack of an eastern shrine is probably the result of heavy downhill erosion of this section of the site. The 
comparison of mean cupule width and depth (excluding Kayé 2 which was comprised of a softer conglomerate material compared to the other six granite kayé) yields a similar pattern as Ku'owingeh: these kayé are slightly deeper than the others and likely represent Xayeh T'a Pingeh that were used by the entire community (Table 5).

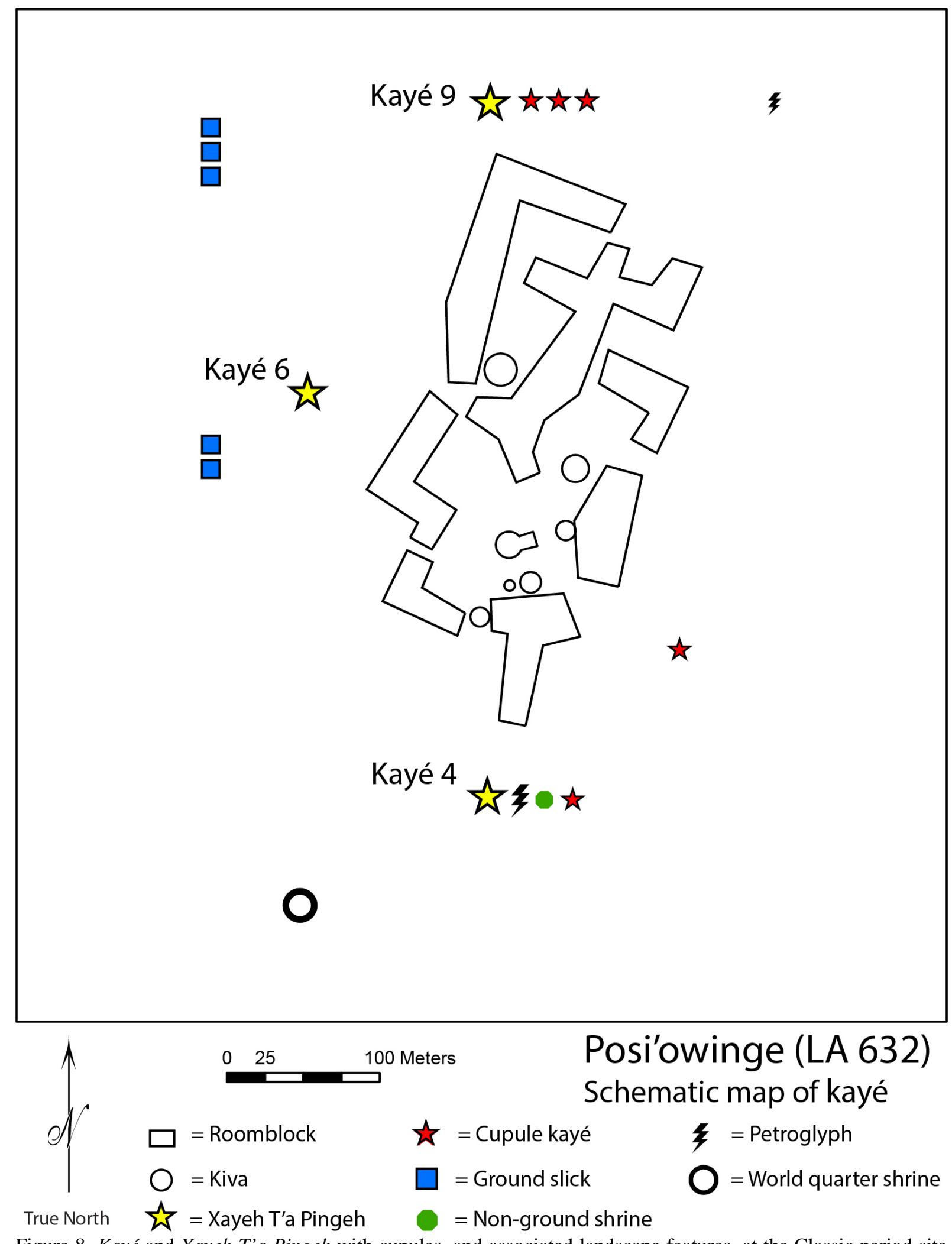

Figure 8. Kayé and Xayeh T'a Pingeh with cupules, and associated landscape features, at the Classic period site of Posi'owingeh. [NOTE (23 JUNE 2017): This figure has been modified at the request of the author.] 
Xayeh T'a Pingeh serve multiple purposes: as a point of departure for the deceased's spirit, the principle village shrines that demarcate the third tier in Tewa cosmography, and the cosmographic representation of the four-directional Tewa world. Their presence at Classic period sites signifies a social and cosmological organization similar to the historic and modern Tewa that includes conceptions of life and death, space, and time. But they also represent the continuation of an ancient tradition of pounding cupules on specific boulders and cobbles surrounding a village. These practices of prayer and offering, introduced to the Chama in the thirteenth century by settlers with different histories and beliefs, were negotiated and transformed in the process of Tewa becoming.

\section{Discussion and conclusions: Becoming Tewa and the future of cupule research}

Tewa history, as told by the Tewa themselves (Ortiz 1969: 13-16; Parsons 1994: 9-15), is a story of both continuity and change. From their emergence into this world to the settling of modern villages, the Tewa view their own history as a dynamic and living process. While key elements of the Tewa cosmos and society have always been with the people, migration experiences and the amalgamation of people with diverse backgrounds and beliefs were essential in shaping culture and cosmology. This Tewa theory of history, with its neverchanging and ever-changing (sensu Rappaport 1992) character of both time and space, is called 'becoming' (Swentzell 1990; Naranjo 2008). Becoming both encapsulates the malleability of the Tewa people and their ideas, as well as the cultural continuity and resilience of their beliefs.

It should therefore not be surprising that this current archaeological study that examines cupules and kayé from ancestral Tewa sites demonstrates similar processes of continuity and change. Cupule width is statistically similar between the Late Coalition, Classic, and Historic periods suggesting that the practice of creating a cupule, and perhaps also the meaning of this practice as an act of prayer, also remained similar through time. The content and context of these prayers, however, likely changed as a result of the dramatic residential, social, and cosmological transformation. Kayé, although likely present in the Late Coalition period, were more homogenized and structured in the Classic period. This signifies a newly developed cosmography which includes features that resemble those described in Tewa ethnography such as Xayeh T'a Pingeh which indicates newly expressed ideas of life and death and the shape and nature of the cosmos. How the negotiation of this new cosmos occurred is currently unknown and will require finer-detailed morphological and chronological analyses. It is important to note, however, that the Tewa cosmos described in the ethnographic record was not cut from whole cloth and was likely the result of the amalgamation and transformation of earlier beliefs and practices.

According to the Tewa (Naranjo 2008) the process of becoming is never complete, and old ideas are reinterpreted based on new situations. When the Spanish colonized New Mexico the Tewa were constrained to live in their villages on the Rio Grande. But the people never ceded their traditional lands, including the Rio Chama watershed. The kayé on the tops of ruined adobe at Ku'owingeh testify to this fact. Cupule morphology is similar to that of earlier periods, signifying similar practices of prayer and offering, but in the new context of pilgrimage through their ancient and sacred landscape.

The study of Tewa history provides archaeologists interested in the global study of cupules three points for consideration. The first is that the creation of cupules themselves was not necessarily the goal of people in the past, but rather cupules were the consequence of human action. For the Tewa this takes the form of prayer but these practices likely vary widely across human communities in time and space. By examining these practices in concert with additional lines of evidence (such as gender, kinship, and social and ceremonial 
organization) archaeologists can begin to explore the dynamics of who was creating cupules and the relationship between these groups and their larger world.

Second, Tewa history demonstrates how a people of the same cultural tradition altered the context of their cupule-making practice within a hundred years. Archaeologists must be cautious when applying ethnographic analogy and particularly the direct historical approach. However, a temporal, practice-based perspective also offers new possibilities in cupule studies. Cupules are unique in that they are an indelible reminder of how people were interacting with their society and their cosmos and thus provide the archaeologists a crucial understanding of how these practices changed (or not) in the context of history.

Lastly, cupules are best studied not in a vacuum but instead in their larger archaeological context. This Tewa case study demonstrated the fruitfulness of comparing both morphological and landscape context data to understand temporal variability. While I relied heavily on ethnographic data, the patterns revealed in these analyses would still be meaningful without the accompanying descriptions from twentieth century Tewa sources (e.g., similar cupule width through time and the unusual Xayeh T'a Pingeh). Therefore, if viewed as human practice, even archaeologists working without relevant ethnography can create insightful interpretations of cupules regardless of knowledge of their inherent cultural symbolism and meaning.

\section{Acknowledgements}

Funding for the Rio Chama kayé survey was provided by a Dissertation Improvement Grant from the National Science Foundation (\#0741708) and a Junior Faculty Fellowship through the University of Oklahoma College of Arts and Sciences (CAS). Special thanks to the Santa Fe National Forest, Bureau of Land Management - Taos Field Office, and The Archaeological Conservancy for support in making this research possible. I am indebted to K. Anschuetz, J. Duwe, M. Duwe, N. Farrell, R. Ford, S. Fowles, K. Heupel, K. Jenks, K. Paul Jones, W. Reitze, and K. Swarts for their help in identifying and recording Tewa landscapes. K. Anschuetz, S. Fowles, K. Newton, the organizers and participants of the Ground Stone Tools, Artefacts, and Society conference 2015 (University of Haifa), and an anonymous reviewer offered valuable critique and insight on earlier drafts of this paper.

\section{References}

Anschuetz, K. 1998, Not Waiting For The Rain: Integrated Systems Of Water Management By Pre-Columbian Pueblo Farmers In North-Central New Mexico. Unpublished Master thesis at the Department of Anthropology, University of Michigan, Ann Arbor, 704 p.

Barrett, E.M. 2002, The geography of the Rio Grande Pueblos in the seventeenth century. Ethnohistory, 49(1): 123-169. doi:10.1215/00141801-49-1-123

Bednarik, R.G. 1994, The discrimination of rock markings. Rock Art Research, 11: 23-24.

Bednarik, R.G. 2008, Cupules. Rock Art Research, 25(1): 61-100.

Bednarik, R.G., Kumar, G., Watchman, A., \& Roberts, R.G. 2005, Preliminary results of the EIP project. Rock Art Research, 22(2): 147-197.

Brück, J. 1999, Ritual and rationality: Some problems of interpretation in European archaeology. European Journal of Archaeology, 2(3): 313-344.

doi:10.1179/146195799799726487 
Bugé, D.E. 1978, Preliminary Report: 1978 Excavations at NM-01-1407, Ojo Caliente, New Mexico. Ms. on file, Laboratory of Anthropology, Museum of New Mexico, Santa Fe, $32 \mathrm{p}$.

Cairns, H.C., \& Branagan, D.F. 1992, Artificial patterns on rock surfaces in the Sydney region, New South Wales: Evidence for aboriginal time charts and sky maps? In: State of the Art: Regional Rock Art Studies in Australia and Melanesia, (McDonald, J. \& Haskovek, I.P., Eds.), Occasional AURA Publication Vol. 6, Australian Rock Art Research Association Inc., Melbourne: p. 25-31.

Callahan, K.L. 2004, Pica, geophagy, and rock-art in the eastern United States. In: The rockArt of Eastern North America: Capturing Images and Insight, (Diaz-Granado, C. \& Duncan, J.R., Eds.), University of Alabama Press, Tuscaloosa: p. 65-774.

Cameron, C. 1999, Room size, organization of construction, and archaeological interpretation in the Puebloan southwest. Journal of Anthropological Archaeology, 18(2): 201-239. doi:10.1006/jaar.1999.0336

Clegg, J. 2007, Science and Rock Art Research of the World. In: Exploring the Mind of Ancient Man (Festschrift to Robert G. Bednarik), (Chenna Reddy, P., Ed.), Research India Press, New Delhi: p. 52-60.

Duwe, S. 2011, The Prehispanic Tewa World: Space, Time, and Becoming in the Pueblo Southwest. Ph.D Dissertation at the School of Anthropology, University of Arizona, Tucson, $858 \mathrm{p}$.

Duwe, S., \& Anschuetz, K. 2013, Ecological uncertainty and organizational flexibility on the prehispanic Tewa landscape: Notes from the northern frontier. In: Mountain and Valley: Understanding Past Land Use in the Northern Rio Grande Valley, (Vierra, B., Ed.), University of Utah Press, Salt Lake City: p. 95-112.

Duwe, S., Eiselt, B.S., Darling, J.A., Willis, M.D., \& Walker, C. 2015, The pueblo decomposition model: A method for quantifying architectural rubble to estimate population size. Journal of Archaeological Science, 65: 20-31. doi:10.1016/j.jas.2015.10.011

Fewkes, J.W. 1891, A Journal of American Ethnology and Archaeology. Houghton Mifflin, New York, 218 p.

Ford, R.I. 2009, Maatüi'in on the move. Paper presented at the New Mexico Archaeological Council Fall Conference, Albuquerque, November 14, 2009.

Ford, R.I., Schroeder, A.H., \& Peckham, S.L. 1972, Three perspectives on Puebloan prehistory. In: New perspectives on the Pueblos, (Ortiz, A., Ed.), University of New Mexico Press, Albuquerque: p. 19-39.

Fowles, S.M. 2004, The Making of Made People: The Prehistoric Evolution of Hierocracy Among the Northern Tiwa of New Mexico. Unpublished Ph.D. Dissertation at the Department of Anthropology, University of Michigan, Ann Arbor, 1015 p.

Fowles, S. 2009, The enshrined pueblo: Villagescape and cosmos in the northern Rio Grande. American Antiquity, 74(3): 448-466. URL: http://www.jstor.org/stable/20622438

Gilbert, R. 2000, The Devil Lake pothole (Ontario): Evidence of subglacial fluvial processes. Geographie physique et Quaternaire, 54(2): 245-250. doi:10.7202/004823ar 
Harrington, J.P. 1916, The ethnogeography of the Tewa Indians. In: 29th Annual report of the Bureau of American Ethnology for the years 1907-1908. Government Printing Office, Washington, D.C.: p. 29-636.

Hedges, K. 1983a, A re-examination of Pomo baby rocks. American Indian Rock Art, 9: 1021.

Hedges, K. 1983b, The Cloverdale petroglyphs. Rock Art Papers, 1: 57-64.

Heizer, R.F. 1953, Sacred rain-rocks of northern California. University of California Archaeological Survey, Report 22. Reports of the University of California Archaeological Survey, 20: 33-38.

URL: http://digitalassets.lib.berkeley.edu/anthpubs/ucb/text/ucas020-004.pdf

Jeançon, A. 1911, Explorations in the Chama basin, New Mexico. Records of the Past, 10: 92-108.

Jeançon, A. 1923, Excavations in the Chama valley, New Mexico. Bulletin 81, Bureau of American Ethnology, Washington, D.C, 166 p.

Kumar, G., \& Ram, K. 2014, Understanding the technology of the Daraki-Chattan cupules: The Cupule Replication Project. Rock Art Research, 31(2): 177-186.

Muehlberger, W.R. 1960, Precambrian rocks of the Tusas Mountains, Rio Arriba County, New Mexico. In: Guidebook to the Rio Chama County, 11th Field Conference, (Beaumont, E.C., \& Read, C.B., Eds.), New Mexico Geological Society, New Mexico: p. 45-47.

Naranjo, T. 2008, Life as movement: A Tewa view of community and identity. In: The Social Construction of Communities: Agency, Structure, and Identity in the Prehispanic Southwest, (Varien, M.D., \& Potter, J.M., Eds.), AltaMira Press, New York: p. 251262.

Nelh, G. 1986, La Grotte Boussaingault, Boigneville. Bulletin du Gersar, 26: 25-42.

Odak, O. 1992, Cup-marks patterns as an interpretation strategy in some southern Kenyan petroglyphs. In: Rock Art of the Old World: Papers Presented in Symposium A of the AURA Congress, Darwin (Australia) 1988, (Lorblanchet, M., Ed.), IGNCA Rock Art Series Vol. 1, Indira Gandhi National Centre for the Arts, New Delhi: p. 49-60.

Ortiz, A. 1969, The Tewa World: Space, Time, Being, and Become in a Pueblo Society. University of Chicago Press, Chicago, 197 p.

Ortman, S. 2012, Winds from the North: Tewa Origins and Historical Anthropology. University of Utah Press, Salt Lake City, 520 p.

Parsons, E.C. 1929, The Social Organization of the Tewa of New Mexico. The American Anthropological Association, Menasha, Wis, 309 p.

Parsons, E.C. 1994, Tewa Tales. University of Arizona Press, Tucson, 304 p.

Pauketat, T. 2001, Practice and history in archaeology: An emerging paradigm. Anthropological Theory, 1(1): 73-98. doi:10.1177/146349960100100105

Rappaport, R.A. 1992, Ritual, time, and eternity. Zygon, 27(1): 5-30. doi:10.1111/j.1467-9744.1992.tb00996.x

Smith, H.T.U. 1938, Tertiary geology of the Abiquiu quadrangle. Journal of Geology, 46: 933-965. doi:10.1086/624710 
Snead, J.E. 2008, Ancestral Landscapes of the Pueblo World. University of Arizona Press, Tucson, $258 \mathrm{p}$.

Spier, L. 1930, Klamath ethnography. University of California Publications in American Archaeology and Ethnology, 30: 1-338.

URL: http://digitalassets.lib.berkeley.edu/anthpubs/ucb/text/ucp030-001.pdf

Stevenson, T.E. 1887, The religious life of the Zuni child. In: Fifth Annual Report of the Bureau of American Ethnology. Government Printing Office, Washington, D.C.: p. 533555.

Swentzell, R. 1990, Pueblo space, form, and mythology. In: Pueblo style and regional architecture, (Markovich, N.C., Preiser, W.F.R., \& Sturm, F., Eds.). Van Nostrand Reinhold, New York: p. 23-30.

Trott, J.J., \& Taylor, M. 1994, Tsiping ruin: Stabilization assessment and preservation plan. Report No. 1994-10-010, Manuscript on file, National Park Service, Southwest Regional Office, Santa Fe, 156 p. 